\title{
Pengaruh Kompetensi dan Pengembangan Karir terhadap Kinerja Karyawan pada PT. Berkah Cemerlang di Jakarta
}

\author{
${ }^{1}$ Denok Sunarsi, Irfan Rizka Akbar ${ }^{2 *}$, Dodi Prasada ${ }^{3}$, Lily Setyawati Kristianti ${ }^{4}$, Henita Sri \\ Muliani $^{5}$, Nidya Sri Anjayani ${ }^{6}$, Hendra $^{7}$ \\ 1,2,3,4 Universitas Pamulang \\ ${ }^{5,6,7}$ STAB Dharma Widya
}

\author{
Alamat Surat \\ Email: ${ }^{1}$ denoksunarsi@unpam.ac.id, ${ }^{2}$ dosen02603@unpam.ac.id*
}

Article History:

Received: 30-Oktober-2020; Received in Revised: 5-Nopember-2020; Accepted: 10-Nopember-2020

\begin{abstract}
ABSTRAK
Penelitian ini bertujuan untuk mengetahui pengaruh kompetensi dan pengembangan karir terhadap kinerja karyawan pada PT. Berkah Cemerlang di Jakarta. Metode yang digunakan adalah explanatory research dengan teknik analisis menggunakan analisis statistik dengan pengujian regresi, korelasi, determinasi dan uji hipotesis. Hasil penelitian ini kompetensi berpengaruh signifikan terhadap kinerja karyawan sebesar 53,7\%, uji hipotesis diperoleh $t$ hitung $>\mathrm{t}$ tabel atau $(7,616>2,009)$. Pengembangan karir berpengaruh signifikan terhadap kinerja karyawan sebesar $45,1 \%$, uji hipotesis diperoleh $t$ hitung $>t$ tabel atau $(6,408>2,009)$. Kompetensi dan pengembangan karir secara simultan berpengaruh signifikan terhadap kinerja karyawan dengan persamaan regresi $\mathrm{Y}=7,939+0,417 \mathrm{X} 1+$ 0,390X2 dan kontribusi pengaruh sebesar $63,4 \%$, uji hipotesis diperoleh $\mathrm{F}$ hitung $>\mathrm{F}$ tabel atau $(42,449>2,790)$.
\end{abstract}

Kata kunci: Kompetensi, Pengembangan Karir, Kinerja Karyawan

ABSTRACT

This study aims to determine the effect of competence and career development on employee performance at PT. Bright Blessings in Jakarta. The method used is explanatory research with analysis techniques using statistical analysis with regression testing, correlation, determination, and hypothesis testing. The results of this study, competence has a significant effect on employee performance by 53.7\%, the hypothesis test obtained $t$ count $>t$ table or $(7,616>2,009)$. Career development significantly affects employee performance by 45.1\%; hypothesis testing is obtained $t$ count> $t$ table or (6.408> 2.009). Competence and career development simultaneously have a significant effect on employee performance with the regression equation $Y=7.939+0.417 X 1+$ $0.390 X 2$, and the contribution of the effect is $63.4 \%$, the hypothesis test obtained $F$ count $>F$ table or (42.449> 2.790).

Keywords: Competence, Career Development, Employee Performance

\section{PENDAHULUAN}

Dalam suatu organisasi, sumber daya manusia merupakan asset tidak berwujud yang berharga. Kemajuan Teknologi dalam era 4.0 membawa perubahan signifikan baik dari segi perilaku dan kemampuan (skill) yang harus di miliki harus dengan cepat menyesuaikan dengan perkembangannya. Dalam hal ini diperlukan Organisasi/Perusahaan yang kondusif, sehingga dapat tumbuh dan berkembang dengan sumber daya manusia sebagai ujung tombaknya, sehingga organisasi dapat memberikan kontribusi kepada perusahaan, sehingga dapat memaksimalkan laba yang diperolehnya. 
Ketika kita berbicara mengenai kompetensi, maka bukanlah hal yang mudah, karena kompetensi harus selalu di asah guna mendapatkan sumber daya manusia yang dapat menyesuaikan diri dengan perkembangan jaman. Perusahaan yang tidak dapat menyesuaikan diri dengan perkembangan jaman maka perlahan-lahan akan tereleminasi dengan sendirinya.

Peningkatan kompetensi dalam sebuah perusahaan adalan hal yang mutlak apalagi jika dihubungkan dengan digitalisasi serta masa Pandemi Covid-19. Pengembangan bukan hanya mencakup aspek soft skill karyawan naming juga penguasaan teknologi informasi. Kompetensi sangat berpengaruh kepada perjalana karir karyawan di perusahaan, bila seorang karyawan tidak dberikan program peningkatan kompetensi maka secara tidak langsung juga akan membawa kemunduran bagi perusahaan. Namun ada kalianya meskipun perusahaan telah membuat dan mengikutsertakan karyawannya dalam peningkatan kompetensi, ditemui tidak adanya peningkatan terhadap kinerjanya.

Hal ini dapat dikarenakan beberapa faktot yang berhubungan dengan sikap dan sifat dari karyawan tersebut. Penelitian ini bertujuan untuk mengetahui pengaruh secara simultan Antara kompetensi, pengembangan karir dan motivasi kerja terhadap kinerja kayawan, untuk mengetahui pengaruh secara parsial Antara kompetensi dan pengembangan karir terhadap kinerja karyawan.

\subsection{Kajian Pustaka Kompetensi}

Menurut Wibowo (2010) kompetensi adalah suatu kemampuan untuk melaksanakan atau melakukan suatu pekerjaan atau tugas yang dilandasi atas keterampilan dan pengetahuan serta didukung oleh sikap kerja yang dituntut oleh pekerjaan tersebut. kompetensi adalah merupakan karakteristik yang dimiliki oleh seseorang sehingga dapat membedakan antara hasil kerja dari satu individu terhadap individu lainnya.

Sedangkan faktor-faktor yang mempengaruhi kompetensi menurut Zwell dalam Wibowo (2010) adalah sebagai berikut: (1) Keyakinan dan Nilai-Nilai (2) Keterampilan (3) Pengalaman (4) Karakteristik Kepribadian (5) Motivasi (6) Isu Emosional (7) Kemampuan Intelektual dan (8) Budaya Organisasi.

\section{Pengembangan Karir}

Sunyoto (2002) menyatakan bahwa pengembangan karir adalah salah satu fungsi dari manajemen karir. Pengembangan karir adalah proses mengidentifikasi potensi karir pegawai dan materi serta menerapkan cara-cara yang tepat untuk mengembangakan potensi tersebut. Pengembangan karir dimulai dengan mengevaluasi kinerja pegawai (performance appraisal). Sedangkan menurut Handoko dalam Megita (2014) pengembangan karir adalah peningkatan pribadi yang dapat di lakukan seseorang untuk mencapai suatu rencana karir yang telah direncanakan. Tujuan pengembangan karir untuk menyesuaiakan kebutuhan pegawai dengan kesempatan karir yang tersedia disuatu organisasi atau instansi pemerintah.

Pengembangan karir dalam organisasi tergantung pada kebijakan dari organisasi itu sendiri dalam menerapkan sistem yang berkaitan dengan karir dari karyawannya tersebut. Namun pada umumnya pengembangan karir dilakukan melalui Pendidikan dan pelatihan, promosi, demosi, serta rotasi jabatan (Nitisemito, 2001).

Adapun faktor-faktor yang mempengaruhi perkembangan karir karyawan menurut Siagian (2007) adalah Prestasi kerja yang memuaskan, Pengenalan oleh pihak lain, Kesetiaan pada organisasi, Pembimbing dan sponsor, dan Peluang untuk tumbuh.

\section{Kinerja Karyawan}

Menurut Mangkunegara (2016:75) pengertian kinerja adalah hasil kerja secara kualitas dan kuantitas yang dicapai oleh seorang pegawai dalam melaksanakan tugasnya sesuai dengan tanggung jawab yang diberikan kepadanya 


\section{METODE}

Penelitian ini adalah jenis penelitian Kuantitatif, dalam penelitian ini yang menjadi populasi adalah semua karyawan PT. Berkah Cemerlang di Jakarta. Karena populasi banyak maka penulis mengambil sample sebanyak 52 orang yang merupakan sampel jenuh. Jenis penelitian yang dipakai adalah asosiatif, dimana tujuannya adalah untuk mengetahui pengaruh antara variabel bebas terhadap variabel terikat baik parsial maupun simultan Dalam menganalisis data digunakan uji instrumen, uji asumsi klasik, regresi, koefisien determinasi dan uji hipotesis

\section{HASIL DAN PEMBAHASAN}

\subsection{Hasil}

\section{Analisis Deskriptif}

Pada pengujian ini digunakan untuk mengetahui skor minimum dan maksimum, mean score dan standar deviasi dari masing-masing variabel. Adapun hasilnya sebagai berikut:

Tabel Hasil Analisis Descriptive Statistics

\begin{tabular}{lr|r|r|r|r} 
& \multicolumn{2}{c}{ Descriptive Statistics } & & \\
& N & \multicolumn{1}{c}{ Minimum } & Maximum & Mean & Std. Deviation \\
\hline Kompetensi (X1) & 52 & 30 & 48 & 37.12 & 4.613 \\
\hline Pengembangan karir (X2) & 52 & 28 & 48 & 37.52 & 3.589 \\
\hline Kinerja Karyawan (Y) & 52 & 32 & 48 & 38.08 & 3.709 \\
\hline Valid N (listwise) & 52 & & & & \\
\hline
\end{tabular}

Kompetensi diperoleh varians minimum sebesar 30 dan varians maximum 48 dengan mean score sebesar 37,12 dengan standar deviasi 4,613. Pengembangan karir diperoleh varians minimum sebesar 28 dan varians maximum 48 dengan mean score sebesar 37,52 dengan standar deviasi 3,589. Kinerja karyawan diperoleh varians minimum sebesar 32 dan varians maximum 48 dengan mean score sebesar 38,08 dengan standar deviasi 3,709.

\section{Analisis Verifikatif.}

Pada analisis ini dimaksudkan untuk mengetahui pengaruh variabel independen terhadap variabel dependen. Adapun hasil pengujian sebagai berikut:

\section{Analisis Regresi Linier Berganda}

Uji regresi ini dimaksudkan untuk mengetahui perubahan variabel dependen jika variabel independen mengalami perubahan. Adapun hasil pengujiannya sebagai berikut:

\section{Tabel Hasil Pengujian Regresi Linier Berganda}

\begin{tabular}{|c|c|c|c|c|c|}
\hline \multirow[b]{3}{*}{ Model } & \multicolumn{2}{|c|}{ Coefficients $^{\mathrm{a}}$} & \multirow{3}{*}{$\begin{array}{l}\text { Standardized } \\
\text { Coefficients }\end{array}$} & \multirow[b]{3}{*}{$\mathrm{t}$} & \multirow[b]{3}{*}{ Sig. } \\
\hline & \multicolumn{2}{|c|}{$\begin{array}{l}\text { Unstandardized } \\
\text { Coefficients }\end{array}$} & & & \\
\hline & $\mathrm{B}$ & Std. Error & & & \\
\hline 1 (Constant) & 7.939 & 3.466 & & 2.290 & .026 \\
\hline Kompetensi (X1) & .417 & .084 & .519 & 4.952 & .000 \\
\hline Pengembangan karir (X2) & .390 & .108 & .378 & 3.603 & .001 \\
\hline
\end{tabular}

a. Dependent Variable: Kinerja Karyawan (Y)

Berdasarkan hasil pengujian pada tabel di atas, diperoleh persamaan regresi $\mathrm{Y}=7,939+0,417 \mathrm{X} 1+$ 0,390X2. Dari persamaan tersebut dijelaskan sebagai berikut: 
a. Konstanta sebesar 7,939 diartikan jika kompetensi dan pengembangan karir tidak ada, maka telah terdapat nilai kinerja karyawan sebesar 7,939 point.

b. Koefisien regresi kompetensi sebesar 0,417, angka ini positif artinya setiap ada peningkatan kompetensi sebesar 0,417 maka kinerja karyawan juga akan mengalami peningkatan sebesar 0,417 point.

c. Koefisien regresi pengembangan karir sebesar 0,390, angka ini positif artinya setiap ada peningkatan pengembangan karir sebesar 0,390 maka kinerja karyawan juga akan mengalami peningkatan sebesar 0,390 point.

\section{Analisis Koefisien Korelasi}

Analisis koefisien korelasi dimaksudkan untuk mengetahui tingkt kekuatan hubungan dari variabel independen terhadap variabel dependen baik secara parsial maupun simultan. Adapun hasil pengujian sebagai berikut:

Tabel Hasil Pengujian Koefisien Korelasi Kompetensi Terhadap Kinerja Karyawan.

\section{Correlations $^{\mathrm{b}}$}

\begin{tabular}{llr|r} 
& & Kompetensi (X1) & Kinerja Karyawan (Y) \\
\hline Kompetensi (X1) & Pearson Correlation & 1 & $.733^{* *}$ \\
\cline { 2 - 4 } & Sig. (2-tailed) & & .000 \\
\hline Kinerja Karyawan (Y) & Pearson Correlation & $.733^{* *}$ & 1 \\
\cline { 2 - 4 } & Sig. (2-tailed) & .000 & \\
\hline
\end{tabular}

Berdasarkan hasil pengujian diperoleh nilai korelasi sebesar 0,733 artinya kompetensi memiliki hubungan yang kuat terhadap kinerja karyawan.

Tabel Hasil Pengujian Koefisien Korelasi Pengembangan karir Terhadap Kinerja Karyawan.

\begin{tabular}{|c|c|c|c|}
\hline \multicolumn{4}{|c|}{ Correlations $^{\mathbf{b}}$} \\
\hline & & $\begin{array}{c}\text { Pengembangan } \\
\text { karir (X2) }\end{array}$ & Kinerja Karyawan $(\mathrm{Y})$ \\
\hline \multirow[t]{2}{*}{ Pengembangan karir (X2) } & Pearson Correlation & 1 & $.671^{* *}$ \\
\hline & Sig. (2-tailed) & & .000 \\
\hline \multirow[t]{2}{*}{ Kinerja Karyawan (Y) } & Pearson Correlation & $.671^{* *}$ & 1 \\
\hline & Sig. (2-tailed) & .000 & \\
\hline
\end{tabular}

Berdasarkan hasil pengujian diperoleh nilai korelasi sebesar 0,671 artinya pengembangan karir memiliki hubungan yang kuat terhadap kinerja karyawan.

Tabel Hasil Pengujian Koefisien Korelasi Kompetensi dan Pengembangan karir secara simultan Terhadap Kinerja Karyawan.

\section{Model Summary}

\begin{tabular}{|c|c|c|c|c|}
\hline \multicolumn{5}{|c|}{ 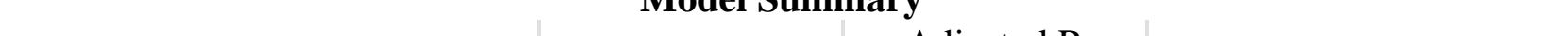 } \\
\hline Model & $\mathrm{R}$ & R Square & $\begin{array}{l}\text { Adjusted R } \\
\text { Square }\end{array}$ & Std. Error of the Estimate \\
\hline 1 & $.796^{\mathrm{a}}$ & .634 & .619 & 2.289 \\
\hline
\end{tabular}

a. Predictors: (Constant), Pengembangan karir (X2), Kompetensi (X1)

Berdasarkan hasil pengujian diperoleh nilai korelasi sebesar 0,796 artinya kompetensi dan pengembangan karir secara simultan memiliki hubungan yang kuat terhadap kinerja karyawan. 


\section{Analisis Koefisien Determinasi}

Analisis koefisien determinasi dimaksudkan untuk mengetahui besarnya persentase pengaruh dari variabel independen terhadap variabel dependen baik secara parsial maupun simultan. Adapun hasil pengujian sebagai berikut:

Tabel 6. Hasil Pengujian Koefisien Determinasi Kompetensi Terhadap Kinerja Karyawan.

\begin{tabular}{|c|c|c|c|c|}
\hline \multicolumn{5}{|c|}{ Model Summary } \\
\hline Model & $\mathrm{R}$ & R Square & $\begin{array}{l}\text { Adjusted R } \\
\text { Square }\end{array}$ & $\begin{array}{l}\text { Std. Error of the } \\
\text { Estimate }\end{array}$ \\
\hline 1 & $.733^{\mathrm{a}}$ & .537 & .528 & 2.549 \\
\hline
\end{tabular}

a. Predictors: (Constant), Kompetensi (X1)

Berdasarkan hasil pengujian diperoleh nilai determinasi sebesar 0,537 artinya kompetensi memiliki kontribusi pengaruh sebesar 53,7\% terhadap kinerja karyawan.

Tabel Hasil Pengujian Koefisien Determinasi Pengembangan karir Terhadap Kinerja Karyawan.

\section{Model Summary}

\begin{tabular}{|c|c|c|c|c|}
\hline Mode & $\mathrm{R}$ & R Square & $\begin{array}{c}\text { Adjusted R } \\
\text { Square }\end{array}$ & $\begin{array}{c}\text { Std. Error of the } \\
\text { Estimate }\end{array}$ \\
\hline 1 & $.671^{\mathrm{a}}$ & .451 & .440 & 2.776 \\
\hline
\end{tabular}

a. Predictors: (Constant), Pengembangan karir (X2)

Berdasarkan hasil pengujian diperoleh nilai determinasi sebesar 0,451 artinya pengembangan karir memiliki kontribusi pengaruh sebesar $45,1 \%$ terhadap kinerja karyawan.

Tabel Hasil Pengujian Koefisien Determinasi Kompetensi dan Pengembangan karir Terhadap Kinerja Karyawan.

\section{Model Summary}

\begin{tabular}{|c|c|c|c|c|}
\hline \multicolumn{5}{|c|}{ Mivouer Summary } \\
\hline Model & $\mathrm{R}$ & R Square & $\begin{array}{l}\text { Adjusted R } \\
\text { Square }\end{array}$ & $\begin{array}{l}\text { Std. Error of the } \\
\text { Estimate }\end{array}$ \\
\hline 1 & $.796^{\mathrm{a}}$ & .634 & .619 & 2.289 \\
\hline
\end{tabular}

a. Predictors: (Constant), Pengembangan karir (X2), Kompetensi (X1)

Berdasarkan hasil pengujian diperoleh nilai determinasi sebesar 0,634 artinya kompetensi dan pengembangan karir secara simultan memiliki kontribusi pengaruh sebesar $63,4 \%$ terhadap kinerja karyawan, sedangkan sisanya sebesar 36,6\% dipengaruhi faktor lain.

\section{Uji Hipotesis}

\section{Uji hipotesis Parsial (Uji t)}

Pengujian hipotesis dengan uji t digunakan untuk mengetahui hipotesis parsial mana yang diterima. Hipotesis pertama: Terdapat pengaruh yang signifikan antara kompetensi terhadap kinerja karyawan.

Tabel Hasil Uji Hipotesis Kompetensi Terhadap Kinerja Karyawan.

\section{Coefficients $^{\mathrm{a}}$}

Unstandardized

Model

Coefficients

Standardized

Coefficients

B

Std. Error

Beta 


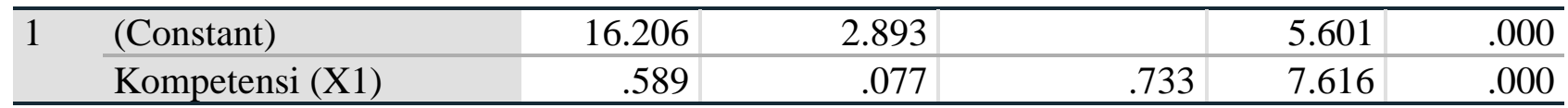

a. Dependent Variable: Kinerja Karyawan (Y)

Berdasarkan hasil pengujian pada tabel di atas, diperoleh nilai thitung $>\mathrm{t}$ tabel atau $(7,616>2,009)$, dengan demikian hipotesis pertama yang diajukan bahwa terdapat pengaruh yang signifikan atara kompetensi terhadap kinerja karyawan diterima.

Tabel Hasil Uji Hipotesis Pengembangan karir Terhadap Kinerja Karyawan.

\begin{tabular}{|c|c|c|c|c|c|}
\hline \multirow[b]{3}{*}{ Model } & \multicolumn{2}{|c|}{ Coefficients $^{\mathrm{a}}$} & \multirow[b]{2}{*}{$\begin{array}{l}\text { Standardized } \\
\text { Coefficients }\end{array}$} & \multirow[b]{3}{*}{$\mathrm{t}$} & \multirow[b]{3}{*}{ Sig. } \\
\hline & \multicolumn{2}{|c|}{$\begin{array}{l}\text { Unstandardized } \\
\text { Coefficients }\end{array}$} & & & \\
\hline & $\mathrm{B}$ & Std. Error & Beta & & \\
\hline $1 \quad$ (Constant) & 12.040 & 4.082 & & 2.950 & .005 \\
\hline Pengembangan karir (X2) & .694 & .108 & .671 & 6.408 & .000 \\
\hline
\end{tabular}

a. Dependent Variable: Kinerja Karyawan (Y)

Berdasarkan hasil pengujian pada tabel di atas, diperoleh nilai t hitung $>\mathrm{t}$ tabel atau $(6,408>2,009)$, dengan demikian hipotesis kedua yang diajukan bahwa terdapat pengaruh yang signifikan atara pengembangan karir terhadap kinerja karyawan diterima.

\section{Uji Hipotesis Simultan (Uji F)}

Pengujian hipotesis dengan uji $\mathrm{F}$ digunakan untuk mengetahui hipotesis simultan yang mana yang diterima. Hipotesis ketiga Terdapat pengaruh yang signifikan antara kompetensi dan pengembangan karir terhadap kinerja karyawan.

Tabel Hasil Uji Hipotesis Kompetensi dan Pengembangan karir Terhadap Kinerja Karyawan.

\section{ANOVA ${ }^{a}$}

\begin{tabular}{ll|r|r|r|r|r} 
Model & & Sum of Squares & df & Mean Square & \multicolumn{1}{c|}{ F } & \multicolumn{1}{c}{ Sig. } \\
\hline \multirow{2}{*}{1} & Regression & 444.909 & 2 & 222.454 & 42.449 & $.000^{\mathrm{b}}$ \\
\cline { 2 - 7 } & Residual & 256.783 & 49 & 5.240 & & \\
\cline { 2 - 7 } & Total & 701.692 & 51 & & & \\
\hline
\end{tabular}

Berdasarkan hasil pengujian pada tabel di atas, diperoleh nilai $\mathrm{F}$ hitung $>\mathrm{F}$ tabel atau $(42,449>$ 2,790), dengan demikian hipotesis ketiga yang diajukan bahwa terdapat pengaruh yang signifikan atara kompetensi dan pengembangan karir terhadap kinerja karyawan diterima.

\subsection{Pembahasan}

\section{Pengaruh Kompetensi Terhadap Kinerja Karyawan}

Kompetensi berpengaruh signifikan terhadap kinerja karyawan dengan korelasi sebesar 0,733 atau memiliki hubungan yang kuat dengan kontribusi pengaruh sebesar 53,7\%. Pengujian hipotesis diperoleh nilai t hitung $>\mathrm{t}$ tabel atau $(7,616>2,009)$. Dengan demikian hipotesis pertama yang diajukan bahwa terdapat berpengaruh signifikan antara kompetensi terhadap kinerja karyawan diterima.

\section{Pengaruh Pengembangan karir Terhadap Kinerja Karyawan}

Pengembangan karir berpengaruh signifikan terhadap kinerja karyawan dengan korelasi sebesar 0,671 atau memiliki hubungan yang kuat dengan kontribusi pengaruh sebesar $45,1 \%$. Pengujian hipotesis diperoleh nilai $\mathrm{t}$ hitung $>\mathrm{t}$ tabel atau $(6,408>2,009)$. Dengan demikian hipotesis kedua 
yang diajukan bahwa terdapat berpengaruh signifikan antara pengembangan karir terhadap kinerja karyawan diterima.

\section{Pengaruh Kompetensi dan Pengembangan karir Terhadap Kinerja Karyawan}

Kompetensi dan pengembangan karir berpengaruh signifikan terhadap kinerja karyawan dengan diperoleh persamaan regresi $\mathrm{Y}=7,939+0,417 \mathrm{X} 1+0,390 \mathrm{X} 2$, nilai korelasi sebesar 0,796 atau memiliki hubungan yang kuat dengan kontribusi pengaruh sebesar $63,4 \%$ sedangkan sisanya sebesar 36,6\% dipengaruhi faktor lain. Pengujian hipotesis diperoleh nilai $\mathrm{F}$ hitung $>\mathrm{F}$ tabel atau $(42,449>2,790)$. Dengan demikian hipotesis ketiga yang diajukan bahwa terdapat berpengaruh signifikan antara kompetensi dan pengembangan karir terhadap kinerja karyawan diterima.

\section{KESIMPULAN}

\subsection{Kesimpulan}

a. Kompetensi berpengaruh signifikan terhadap kinerja karyawan dengan kontribusi pengaruh sebesar 53,7\%. Uji hipotesis diperoleh nilai t hitung > t tabel atau $(7,616>2,009)$.

b. Pengembangan karir berpengaruh signifikan terhadap kinerja karyawan dengan kontribusi pengaruh sebesar 45,1\%. Uji hipotesis diperoleh nilai t hitung $>\mathrm{t}$ tabel atau $(6,408>2,009)$.

c. Kompetensi dan pengembangan karir berpengaruh signifikan terhadap kinerja karyawan dengan kontribusi pengaruh sebesar $63,4 \%$ sedangkan sisanya sebesar $36,6 \%$ dipengaruhi faktor lain. Uji hipotesis diperoleh nilai F hitung > F tabel atau $(42,449>2,790)$.

\subsection{Saran}

a. Perusahaan harus meningkatkan kegiatan pendidikan dan pelatihan secara periodik agar karyawan memiliki kemampuan kerja yang lebih baik lagi

b. Perusahaan harus membuat program pengembangan karir guna membantu karyawan dalam mencapai keinginan yang diharapkan terkait dengan bidang pekerjaannya.

c. Kinerja perusahaan dapat ditingkatkan dengan memberdayakan karyawan dengan menegakkan peraturan yang baik dan pemberian pengembangan karir yang lebih inten lagi.

\section{DAFTAR PUSTAKA}

A.A. Anwar Prabu Mangkunegara (2015), Manajamen Sumber Daya Manusia Perusahaan, PT Remaja Rosdakarya, Bandung.

Algifari (2015). Analisis Regresi untuk Bisnis dan Ekonomi. Yogyakarta: BPFE.

D Sunarsi. (2020). Kepemimpinan Bisnis Strategik. Kota Serang: Desanta Muliavisitama.

Cahyono, Y., Purwanto, A., Sukanta, F. N. A., Fitriaty, H. W., Sihotang, M., \& Sugianto, A. (2020). Impact Of Service Quality, University Image And Students Satisfaction Towards Studentloyalty: Evidence From Indonesian Private Universities. Journal of Critical Reviews, 7(19), 3916-3924.

Dharma,Surya (2013), Manajemen Kinerja, Falsafah Teori \& Penerapannya, Pustaka Pelajar, Yogyakarta.

Handoko T. Hani, (2017), Manajemen Personalia dan Sumber Daya Manusia, edisi kedua, BPFE, Yogyakarta.

Hasibuan, Malayu SP (2016), Manajemen Sumber Daya Manusia, Edisi Revisi, Penerbit Bumi Aksara, Jakarta.

Henry Simamora (2015), Manajemen Sumber Daya Manusia, STIE YKPN Bandung.

Imam Ghozali (2017). Aplikasi Analisis Multivariate Dengan Program SPSS. Edisi Kelima. Semarang: Badan Penerbit Undip. 
Istijanto (2014) Riset Sumber Daya Manusia. Jakarta: PT. Gramedia Pustaka

Lukiastuti, Fitri, et.al (2020). The Influence of Entrepreneur's Personal Characteristics on SMES Performance Mediated by Entrepreneurial Orientation. International Journal of Psychosocial Rehabilitation. Volume 24 - Issue 8

Purwanto, A., Sunarsi, D., \& Wijoyo, H. (2020). Penerapan Perluasan Arti Perbuatan Melanggar Hukum Dalam Pelaksanaan UU 29 Tahun 2004 (Studi Kasus Putusan No.625/PDT.G/2014/PN JKT. BRT). TIN: Terapan Informatika Nusantara, 1(2), 99-103.

Sedarmayanti (2015), Sumber Daya Manusia dan Produktivitas Kerja, CV. Mandar Maju, Bandung. Singgih Santoso (2015). Menguasai Statistik Multivariat. Jakarta: PT Elex Media Komputindo.

Sondang, P.Siagian ( 2015), Manajemen Sumber Daya Manusia, Bumi Aksara, Jakarta

Sudjana (2014) Metode Statistika, Bandung: Tarsido.

Sugiyono (2017), Metode Penelitian Administrasi : dilengkapi dengan Metode $R \& D$, Bandung: Alfabeta.

Sunarsi, D. (2018). Buku Ajar: Seminar Perencanaan Sumber Daya Manusia. Tangerang Selatan: Asmoro Mediatama

Sunarsi, D. (2018). Pengembangan Sumber Daya Manusia Strategik \& Karakterisrik Sistem Pendukungnya : Sebuah Tinjauan. Jurnal Ilmiah MEA (Manajemen, Ekonomi, \& Akuntansi), 2(3), 178 - 194.

Sunarsi, D. (2019). Seminar Sumber Daya Manusia. Tangerang Selatan: Unpam Press

Sunarsi, D., Wijoyo, H., Prasada, D., \& Andi, D. (2020, September). PENGARUH LINGKUNGAN KERJA TERHADAP KINERJA KARYAWAN PADA PT. MENTARI PERSADA DI JAKARTA. In Seminar Nasional Manajemen, Ekonomi, Akuntansi (Vol. 5, No. 1, pp. 117123).

Sutrisno, Edy. 2016. Manajemen Sumber Daya Manusia. Yogyakarta: Kencana Prenada Media

Wijoyo, H. (2018). Analisis Pengakuan Pendapatan dan Beban Kontrak Konstruksi Pada PT. Wahana Tata Riau. Jurnal Ilmu Komputer dan Bisnis, 9(2), 2034-2043. 